Article received on $3^{\text {rd }}$ July 2011 Article accepted on $27^{\text {th }}$ February 2012

UDC: 78.071.1 Вајт Џ.

\author{
Virginia Anderson* \\ University of Nottingham \\ Experimental Music Catalogue
}

\title{
JOHN WHITE AND THE ALTERNATIVE BRITISH EXPERIMENTAL AESTHETIC**
}

\begin{abstract}
This paper proposes that the British experimental movement, considered to be 'fringe' to a notional central tradition, is actually the centre of an entirely different tradition in contemporary music. The sonatas and minimalist compositions by the composer John White (1936), rather than the notational experiments of his more famous contemporary Cornelius Cardew, reveal aspects of this alternative experimental and postmodern centre. Keywords: John White, experimentalism, minimalism, systems, Machines, piano sonatas, 'avant postmodernism', alternative history

Апстракт: Рад је заснован на претпоставци да је британски експериментални покрет, који се сматра „маргином“ у односу на претпостављену централну традицију, заправо центар сасвим различите традиције савремене музике. Сонате и минималистичке композиције композитора Џона Вајта (John White, 1936), радије него експерименти у подручју нотације његовог много познатијег савременика Корнелијуса Кардјуа (Cornelius Cardew), откривају аспекте оваквог алтернативног експерименталног и постмодернистичког центра.
\end{abstract}

* Author contact information: vanderson@experimentalmusic.co.uk

** I would like to thank Dave Smith for providing his unpublished catalogue raisonée of White's music and advice, Christopher Hobbs for reading and advice, and John White for invaluable assistance. 
Кључне речи: Џон Вајт, експериментализам, минимализам, системи, Машине (Маchines), клавирске сонате, 'аван-посмодернизам', алтернативна историја

British experimental indeterminacy (ca. 1951-1971), along with its postmodern successor (ca. 1967 to the present), ${ }^{1}$ is considered to be a 'fringe' movement by some. While American indeterminacy falls under the aegis of American music studies, British experimentalism seems to lie in limbo, too European to be an outpost of American experimentalism and too American in theory to be part of the European tradition. It is 'fringed', like a shawl, at both ends of its geographic influences. Like a shawl has its own weft and warp, British experimentalism has its cultural criteria and aesthetic logic. It has its own mainstream of important composers and its own central history. ${ }^{2}$ This article will examine one aspect of that history, with a twist.

A history typically features a single, central composer, often the founder of a movement, with his or her students, colleagues and 'fellow travellers' orbiting him or her as satellites. Cornelius Cardew (1936-81), the founder of experimental music in Britain, is, quite rightly, the 'hero' of the experimental story. ${ }^{3}$ However, John White (1936- ), Cardew's lesser known, but equally important, contemporary, represents the 'alternative' spirit of British experimentalism better than any other composer, including Cardew. White entered the 'normal' British experimental narrative when he performed part of Cardew's great graphic score Treatise (1963-67) in May 1965 by reading ascending lines as descending melodies, what Cardew called a " "perverse" interpretation' ${ }^{4}$ White invented British process minimalism with his 'Machine' music, becoming a leading figure in a trend within British experimentalism for a literate form of postmodern tonality. Like other postmodern art forms, this movement emphasizes the 'alternative' through ironic reference. $^{5}$

1 'Experimental music' here is that described by Michael Nyman, in Experimental Music: Cage and Beyond, Cambridge: CUP, 1999.

${ }^{2}$ The distinction between 'fringe' and 'mainstream' is, admittedly, a mixed metaphor, but it is better than 'fringe' and 'shawl', and kinder than 'mainstream' and 'backwater'.

${ }^{3}$ Histories include John Tilbury (in 'Cornelius Cardew', Contact 26 (1983), 4-11, and Cornelius Cardew: A Life Unfinished, Matching Tye, Essex, Copula, 2008, and my own British Experimental Music: Cornelius Cardew and His Contemporaries, Leicester, Experimental Music Catalogue, 2000 (orig. 1983).

${ }^{4}$ Cornelius Cardew, Treatise Handbook, London, Peters, 1971, ix.

${ }^{5}$ An account of postmodern traits applicable to White and other British postmodernists is found in Jonathan Kramer, 'The Nature and Origin of Postmodern Music', in Postmodern Music/Postmodern Thought, ed. Judy Lochhead and Joseph Auner, New York, Routledge, 2002, 13-26. 
Following White and the pianist John Tilbury, Sarah E. Walker calls this group 'The New English Keyboard School', noting that White has been writing piano music in an 'experimental' ironic style at least since $1962 .{ }^{6}$ However, this experimental style pre-dates White's acknowledged experimental work. White has written elements of 'postmodern' tonality since 1956, before Cardew's first experimental piece in $1960 .{ }^{7}$ Conversely, it seems that these 'avant postmodern'8 sonatas have influenced British experimentalism. John White's distinctive and unorthodox pantheon of influences, as we will see below, creates an alternative history, which is shown through his sonatas and Machines. Finally, White's own attitude to the 'fringe' and mainstream questions whether an alternative mainstream for experimentalism is incompatible with an experimental ethic.

\section{John White and His 'Alternative' History}

White was influenced by what Dave Smith called an 'apparently disparate collection of composers from the world of "alternative" musical history'. ${ }^{9}$ Alkan, Schumann, Busoni, Satie, Reger, Scriabin, Medtner and Bruckner are, perhaps, the abiding influences on White's piano sonatas, but other influences include Messiaen, Rakhmaninov, Kraftwerk and The Residents (the last two are electronic pop ensembles). These influences reflect the eclectic nature of White's postmodernism as well as his personal, alternative aesthetic. They informed White's sonatas as much as British indeterminacy informed his minimalism; both the alternative 'canon' and indeterminacy inform his present-day work.

Born in Berlin in 1936 to an English father and a German mother (the family moved to London in 1939 at the outbreak of war), White has greater genetic ties to Central Europe than many British composers. White is pro-European in his activities and musical tastes and his musical influences are largely European. White naturally should have studied in Continental Europe like many of his contemporaries. Instead, White remained in Britain after his study at the Royal College of Music. As we shall see, White chose not to study elsewhere because of a fascina-

\footnotetext{
${ }^{6}$ Sarah E. Walker, 'The New English Keyboard School: A Second "Golden Age", Leonardo Music Journal, 11 (2001), 18.

${ }^{7}$ Charles Hamm, in 'Privileging the Moment: Cage, Jung, Synchronicity, Postmodernism', Journal of Musicology, 15/2 (1997), 278-289, and elsewhere, shows Cage's 'postmodernism' through elements of discontinuity, but Cage's postmodernism is in a modern experimental language.

${ }^{8}$ David Wright, 'Party Time' [review of Roger Smalley, John White: Piano Sonatas (NMC D038, 1996)], The Musical Times, 138/1848 (1997), 42.

${ }^{9}$ Dave Smith, 'The Piano Sonatas of John White', Contact 21 (1980), 6.
} 
tion with what Brian Dennis jokingly called the 'also-rans of musical history' ${ }^{10}$ His choice also questions whether the central mainstream is the only path to new European music.

White decided to compose upon hearing Messiaen's Turangalîla-Symphonie in its first non-radio London performance on 12 April 1954. 'I was in the half of the audience [that] floated out of the [Royal] Festival Hall six feet above the ground; the other half retired to the lavatory and were sick'. ${ }^{11}$ By 1956, White wrote the first of his piano sonatas, which reminded at least two reviewers of Messiaen at its first performances. ${ }^{12}$ He studied composition at the Royal College of Music from 1955-1958 with Bernard Stevens (1916-83) and analysis privately from Elisabeth Lutyens (1906-83). Neither composer seems to have influenced White stylistically. White felt that Lutyens taught him 'analysis and the nuts and bolts of composition, rather than creative composition'; 13 she used White's piano repertoire as analysis pieces. Stevens, however, had an associational, rather than compositional, influence on White. He gently urged White, unsuccessfully, to write pieces other than 'chorales and arabesques'. ${ }^{14}$ More usefully, Stevens also told White about such early twentieth-century composers (who were then out of fashion) as Kaikhosru Sorabji (1892-1988) and Bernard van Dieren (1887-1936), who became part of White's influences.

White's nearest contemporaries, including Alexander Goehr, Peter Maxwell Davies, Harrison Birtwistle, Cornelius Cardew and Richard Rodney Bennett, plus his fellow students at the Royal College of Music, London, studied either in France with Boulez or Messiaen, Italy with Petrassi, or Germany with Stockhausen. White questioned the effect of this step as detrimental to compositional 'facility'. ${ }^{15}$ Instead, White became the musical director for the Western Theatre Ballet, founded by Elizabeth West and Peter Darrell in 1957 to create dance with a heightened emphasis on drama (hence the 'Theatre' Ballet), and to provide 'an outlet for new designers, composers and choreographers'. ${ }^{16}$ White continued to work throughout his life in dance and theatre, and is presently Director of Music at Drama Centre, London. He became professor of composition at the Royal College of Music

\footnotetext{
${ }^{10}$ Brian Dennis, taped interview with author, Egham, Surrey, 13 February 1983.

${ }^{11}$ John White, interview by author, London, 7 March 1983.

${ }^{12}$ Felix Aprahamian, Review, Sunday Times, 8 March 1959; Anonymous, Review, Bradford Evening Telegraph and Argus, 23 December 1960.

${ }^{13}$ White, interview, op. cit., 1983.

${ }^{14}$ White, interview, op. cit., 1983.

${ }^{15}$ John White, email to author, 21 June 2011.

${ }^{16}$ Annette Massie, 'Elizabeth West and Western Theatre Ballet', Dance Research: The Journal of the Society for Dance Research, 6/1 (1988), 46.
} 
(1961-67), proving that despite his unorthodox interests, his gifts as a composer were appreciated. His students included Brian Dennis (1941-1998) and Roger Smalley (1943-), who, despite White's personal reservations, studied with Stockhausen, Boulez, and Berio.

White's incuriosity about the European avant garde might be blamed on a typical British compositional conservatism, but for his enthusiastic entry into experimental indeterminacy and the alternative 'canon' of his own creation, including his unique approach to the ne plus ultra of genres, the symphony. White has written twenty-five symphonies, not for the standard full orchestra, but rather completely different pieces written for a variety of instruments (including organ and six tubas (No. 2, 1965), four symphonies that are consecutive variations of the first (Nos. 3-6, 1981), and 'The Alpine' (No. 18, 1987), for computer and live electronics). However, as they are a more consistent personal genre, White's piano sonatas best exhibit the implications of his alternative canon.

\section{The 'Avant Postmodernism' of White's Piano Sonatas}

White's 173 sonatas are important to his body of work, as they span his entire compositional life. They also are centrally influential to the work of other British experimentalists. The study of sonatas is just as important to White studies as the study of symphonies is to Beethoven studies. White's musical concerns appear in his sonatas, not in a programmatic way, but rather 'like entries in a diary, [reflecting] the musical interests of the moment'. ${ }^{17}$ Smith wrote that in these sonatas, 'one is likely to encounter a wry humour, the odd "dangerous mood-swing" or an "incomprehensible monument", in styles from 'anything from subversive conservatism to visionary experimentalism'. ${ }^{18}$

White's sonatas may be traced, like Cage's Sonatas and Interludes (194648), to Domenico Scarlatti. Cage followed Scarlatti's use of terse binary and ternary forms; White's sonatas, although more varied, are similarly brief. Although the First Sonata is in three movements (like a Romantic sonata), most of White's sonatas are only one movement and some of them no more than a few bars long. White's sonatas resemble a diary, in that they are 'semi-private pieces': 'They're the result of perhaps hearing a wonderful performance of the Busoni Elegies', ${ }^{19}$ or other works, and so they change with White's interests and associations. Sonatas Nos. 37-52 (1967-72), for instance, are experimental, reflecting White's work

\footnotetext{
${ }^{17}$ White, interview, op. cit., 1983.

${ }^{18}$ Dave Smith, programme notes for concert of White's sonatas, Schott's recital room, 3 September 2010.

${ }^{19}$ White, interview, op. cit., 1983.
} 
with Cardew. These sonatas incorporate elements of White's early systems processes (discussed in the next section) and his experiments with notation. Sonata 39 (19 June 1969) contains a durational process affecting three different strands, their notes coloured in red, turquoise and brown. ${ }^{20}$ Most of White's sources, however, come from his 'enthusiastic absorption with aspects of nineteenth [and early twentieth] century music'. ${ }^{21}$

White has used the analogy of a 'mental digestive process', ${ }^{22}$ resulting in a complex rethinking of musical ideas. He thinks of this process as a kind of discussion.

I see my life in music as being at a party in the company of a lot of extremely interesting and diverse people. I keep encountering new names [including Skalkottas, Lyatoshinsky, Karamanov, Koechlin, and Roslavets], all with something interesting or fun to say.... Some of this rubs off, some just remains in the 'attic', ready to be taken out, dusted down and swung into action. ${ }^{23}$

This discussion can result in a kind of Ivesian diegeticism (as in Central Park in the Dark). White described his 'deliberately non-developmental piece', Sonata 108 (27 July 1983), subtitled 'Reminiscenza di tempo di tango' in a filmic manner.

Where would you hear all these disconnected fragments of bits of tangos? Why, in a Rio de Janeiro bordello, of course! Each room's radio tuned to a different station, audible for a few seconds as the door opened to let a client in or out. ${ }^{24}$

Other sonatas are 'characteristic' pieces. White uses no first-person expression, nor high expressionism of any kind. There is a third-person musical mood: 'a practically physical predilection for a particular kind of sound' ${ }^{25}$ White shows a strong preference for triple and compound metre, often reflecting dance or other physical activity. Most sonatas are dedicated to people who have, presumably, inspired them (No. 114 (27 July 1987) was dedicated to this author). White often adds directions reminiscent of the theatre (No. 55 (19 April 1972) reads, 'as if written for strings by Berlioz and conducted by Beecham'), as well as subtitles. As Satie intended, White also intends his directions to be read by the performer alone.

${ }^{20}$ Dave Smith, 'John White: Volume 1, Piano Sonatas'. Unpublished catalogue raisonée, to be published by the Experimental Music Catalogue, 2012.

${ }^{21}$ White, quoted in Smith, 'The Piano Sonatas of John White', op. cit., 4.

${ }^{22}$ White, interview, op. cit., 1983.

${ }^{23}$ White, email to author, 10 June 2011.

${ }^{24}$ White, email to author, 16 June 2011. Although the tango is Argentine, White's scenario plays out, perversely, in Brazil.

${ }^{25}$ White, interviewed in Smith, 'Piano Sonatas', op. cit., 4. 
Other British experimental composers share White's 'retrospective'26 focus and love of alternative sources. Gavin Bryars (1943-), who worked extensively with White in the 1970s, once listed 'Berlioz, Liszt, Schubert, Mahler, Busoni..., Reger, Karg-Elert, Skryabin, Szymanowski, [and] Satie' as his personal influences. ${ }^{27}$ Brahms will not be found in any of these composers' music in a serious manner. Brahms is satirized in Sonata No. 15 (1962), when 'shades of Brahms and Frank Martin slug it out with Weber for supremacy' ${ }^{28}$ White deplored 'the development noise' in Brahms's work; ${ }^{29}$ Bryars later joked, 'I would like to blow up the entire works of Brahms', in a survey of things to be demolished for the new year. ${ }^{30}$

These composers use genre in a similar manner to White in their own piano music. Christopher Hobbs' (1950- ) Sonatinas include long multi-movement pieces, a joking answer to White's terse sonatas. Dave Smith (1949- ) invented the Piano Concert, single pieces and collections of pieces intended to fill an evening performance. The pieces in collection exhibit interests similar to White, especially titular puns (for Smith, anagrams) and personal dedications. Other composers using a similar approach to piano music include Hugh Shrapnel (1947- ), Benedict Mason in his early music (1954- ), plus some pieces by Brian Dennis, Michael Parsons (1938-), and Howard Skempton (1947-).

These compositions exhibit a similar distanced character to that found in White's sonatas: they are 'about' something rather than 'express' something. Only Cardew's political music, and that of Smith and Shrapnel, affects an emotive subject position. Bryars hides or encodes his references as a structural device; a different, albeit related, approach to White's 'digestion' of sources. Although personal, White's sonatas are not isolated from his other music. Ironic, perverse aspects of White's sonatas were also played out in other areas of musical construction, particularly in White's invention of Machines and establishment of British minimalism.

\footnotetext{
${ }^{26}$ One of three 'shades of radicalism' delineated by David Nicholls (the others being 'prospective' (modernist) and 'extraspective' (exotic) influences), in 'Avant-Garde and Experimental Music', in The Cambridge History of American Music, ed. Nicholls, Cambridge, Cambridge University Press, 1998, 521.

27 'Gavin Bryars [interview], in Paul Griffiths, New Sounds, New Personalities: British Composers of the 1980s, London, Faber Music, Ltd., 1985, 158.

${ }^{28}$ White, programme note for concert by Ian Lake, Blackheath, 1990, quoted in Sarah E. Walker, op. cit., 18.

${ }^{29}$ White, quoted in Michael Nyman, 'Hearing, Seeing', Studio International, 192/984 (1976), 237-8.

${ }^{30}$ Bryars, quoted in David Benedict, 'They'll None of Them be Missed', The Independent, 2 January 1995.
} 
Anderson, V.: John White and the Alternative British Experimental Aesthetic (40-50)

\section{Development of British minimalism}

Such a long section on White's avant postmodernism begs the question of the effect White had on 'proper' British experimentalism. To understand this effect, one must understand the way that minimalism and experimentalism overlapped in America and Britain. In America, two types of early experimental minimalism - 'minimal' minimalism, of few events and long silences (Feldman and Young in the late 1950s), and repetitive or 'process' minimalism (Riley and Reich from 1964-65) - arose simultaneously with, and shortly after, experiments in indeterminacy and notation (from ca. 1951-71). Minimalism lasted until around 1976, when other 'postminimal' compositional styles arose. British experimental indeterminacy started with Cardew's break with Stockhausen in 1960, and ended about 1972. Christopher Hobbs's One Note 1966 may constitute the first 'minimal' minimalist piece. White also began working in 1967 on what would be the first British process minimalism, in which he called his Machines.

When White entered experimental music performance with his 1965 'perverse' interpretation of Treatise, ${ }^{31}$ he said that he learned much from Cardew, particularly for "the "driving decisions"" for compositional choices. This gave White, 'that extra dimension to my awareness of music during music's most confused time, which was the '60s'. ${ }^{32}$ White began with his Machine for Cello and Tuba (1968), in which knight's moves on a chessboard indicated the process for the tuba player; the cello, in part, used a process of increasing and decreasing intervals, with occasional use of pizzicato. White trialled these processes in his sonatas of the time, including Nos. 37, 38, 41, 46, and 50. Cardew played with White in the premiere and created his own Ode Machines, based on White's work, for Paragraph 5 of his monumental experimental work, The Great Learning (1968-71).

From 1969, White held weekly concerts at the New Arts Laboratory, London, for which he wrote Machines. He also wrote Machines for the Promenade Theatre Orchestra (PTO), a four-composer quartet consisting of White, Shrapnel, Hobbs, and Alec Hill. The Arts Lab Machines were played at sight, and therefore had 'easy-to-follow instructions, easy-to-perform musical actions lasting a long time, the result being a sound orientated performance art' ${ }^{33}$ Arts Lab Machines use alternative notation for reading or non-reading players; most employ random compositional processes, or 'systems', to determine the event progression, using uncommon instruments, including blown bottles (Drinking and Hooting Machines, 1970), swanee whistles (Swanee Machine, 1970), or newspapers (News-

\footnotetext{
${ }^{31}$ Cardew, Treatise Handbook, London, Peters, 1971, ix.

${ }^{32}$ White, interview, op. cit., 1983.

${ }^{33}$ White, in Smith, 'White - Ensemble Pieces' (unpublished catalogue raisonée).
} 
paper Reading Machine, ca. 1970). Jew's Harp Machine (also 1970) requires the players to mouth the phonemes, 'Ging, Gang, Gong, Gung, Hö!' in Machine permutations.

The PTO standard instrumentation consisted of four toy pianos, four reed organs, percussion and additional instruments, for which all members wrote. PTO pieces are technical, often virtuosic, despite the instrumentation. The toy instrument sound, along with 'jolly', even 'silly', titles, is a hallmark of White's music from the late 1960s onward. PTO pieces include White's own category, the 'Gothic', such as Gothic Chord Machine (1970), in which Machine processes were applied to thick-textured, heavy bass music (Sonata No. 51 was based on this piece). White also wrote 'readymades', a category associated mainly with Hobbs (and derived from the artist Marcel Duchamp), in which existing music, from Bach to novelty piano pieces, were subjected to systems processes. Other composers include Gavin Bryars, whose best-known piece of this time, Jesus'Blood Never Failed Me Yet (1971), is a readymade of a tramp's song, looped and accompanied by orchestra. Machines and other repetitive process music (for instance, Alec Hill's processes for Large Change and Small Change Machines (1970), borrowed from change-ringing) began about this time to be formally called 'systems' music.

Hobbs and White, working as a duo from 1972-1976, moved from systems processes based on random numbers to 'strict' systems, using number series or permutations. These systems were first applied to duration and played on percussion. Although Parsons and Skempton later used these processes in a duo percussion ensemble, the strict application of numbers to duration alone proved to be a kind of dead end for Hobbs and White, as the resulting pieces, being as strict as serialism, could not be more ascetic. ${ }^{34}$ Hobbs and White moved in about 1974 to what Michael Parsons called 'empirical' music (a better term would be 'eclectic'), a return to the extended tonal world of White's early sonatas. White returned to systems in the 1980s, using cheap home electronic digital keyboards and other electronic processors. Some of White's later systems are deliberately light (for instance, pieces he released under the 'nom de Rock' of Eduard Ratt that include such novelty noises as dog barks, pig grunts, and farts). Systems underlie at least fifteen of White's twenty-five symphonies, including the previously mentioned 'Alpine' Symphony. White has therefore two modes of composition, the eclectic and the 'systemic'. Both of these modes celebrate the immediate, the 'jolly', and

\footnotetext{
${ }^{34}$ Michael Nyman, in 'Against Intellectual Complexity in Music', October 13 (1980), 83, claimed that 'systems music in general is related, however distantly, to serialism', but this refers to Young and Reich, who studied and employed actual serial methods in their early minimalism.
} 
Anderson, V.: John White and the Alternative British Experimental Aesthetic (40-50)

the entirely musical narrative, entrenching White's role (as Keith Potter wrote in 1971), as 'the father figure behind the New [i.e., tonal] Music', and 'something of a counterforce in new English music'. ${ }^{35}$

\section{Assessing White's legacy}

In honour of White's seventieth birthday, nine pianists played forty-eight of his sonatas throughout the afternoon and evening of 9 April 2006 at Wilton's Music Hall, London. Such a tribute proves that White has not worked in isolation; its review, calling White the 'guru figure for several generations of young composers', ${ }^{36}$ shows his centrality to the movement. But this does not tell us whether White is the centre of a fringe, or if he is the centre of an alternate mainstream. When I told him about the 'fringe' theme of this issue, White doubted whether he was 'fringe' or 'mainstream'.

I think there might be debate on whether the definition of Fringe includes an implied ambition to get into the Mainstream (not yet accomplished) or whether its inhabitants (like me, perhaps) are content to make their statements regardless of the size of audience or the prestigiousness [sic] of the performance venue. If something 'Mainstream' were to be proffered (a Proms commission for a piano concerto, for instance), I'd certainly not turn the idea down, but would go for it with enthusiasm, but don't have the basic instinct to whizz around trying to make the correct contacts towards admission to the Mainstream contemporary music scene. ${ }^{37}$

We can question, from this statement, whether proposing an alternative mainstream of British experimentalism transgresses the experimental ethic. Given that White, so important to this group, is so ambivalent, there is something perverse in proposing his centrality for him. White's attitude resembles Groucho Marx's reputed resignation from the Friars' Club: 'I don't want to belong to any club that will accept people like me as a member'. ${ }^{38}$ But then again, just as White's interpretation of Cardew's Treatise was 'perverse', so this centralisation of White, rather than a more culturally sensitive anti-history, may actually provide illumination precisely because it is perverse.

\footnotetext{
${ }^{35}$ Keith Potter, review of 'Music Now' concert, 18 October 1971, Queen Elizabeth Hall, London, Contact 3 (1971), 34.

${ }^{36}$ Keith Potter, 'John White, Wilton's Music Hall, London [review]', The Independent, 14 April 2006.

${ }^{37}$ White, email, 10 June 2011.

${ }^{38}$ Groucho Marx, Groucho and Me, New York, Random House, 1959, 321.
} 


\section{REFERENCES}

Anderson, Virginia, British Experimental Music: Cornelius Cardew and His Contemporaries, Leicester: Experimental Music Catalogue, 2000 (orig. 1983)

Griffiths, Paul, New Sounds, New Personalities: British Composers of the 1980s, London: Faber Music, Ltd., 1985, 158

Groucho Marx, Groucho and Me, New York: Random House, 1959, 321.

Hamm, Charles, 'Privileging the Moment: Cage, Jung, Synchronicity, Postmodernism', in Journal of Musicology, 15/2, 1997, 278-289

Kramer, Jonathan, 'The Nature and Origin of Postmodern Music', Postmodern Music/Postmodern Thought, ed. Judy Lochhead and Joseph Auner, New York: Routledge, 2002, $13-26$.

Massie, Annette, 'Elizabeth West and Western Theatre Ballet', Dance Research: The Journal of the Society for Dance Research, 6/1 (1988), 46

Nicholls, David, 'Avant-Garde and Experimental Music', The Cambridge History of American Music, ed. Nicholls, Cambridge: Cambridge University Press, 1998, 521

Nyman, Michael, 'Against Intellectual Complexity in Music', October 13 (1980), 83

Nyman, Michael, Experimental Music: Cage and Beyond, Cambridge: Cambridge University Press, 1999

Nyman, Michael, 'Hearing, Seeing', Studio International, 192/984, 1976, 237-8

Smith, Dave, 'The Piano Sonatas of John White', Contact 21, 1980, 6

Tilbury, John, Cornelius Cardew: A Life Unfinished, Matching Tye, Essex: Copula, 2008

Tilbury, John, 'Cornelius Cardew', Contact 26, 1983, 4-11

Walker, Sarah E., 'The New English Keyboard School: A Second "Golden Age”, Leonardo Music Journal, 11, 2001, 18

Wright, David, 'Party Time' [review of Roger Smalley, John White: Piano Sonatas (NMC D038, 1996)], The Musical Times, 138/1848, 1997, 42 